\title{
Building and Applying a Human Rights-Based Model for Migrant Integration Policy
}

\section{Clíodhna Murphy, Mary Gilmartin, and Leanne Caulfield*}

\begin{abstract}
The approach of public bodies towards migrant populations is often framed in terms of 'migrant integration'. However, domestic integration policy and practice often come up short in terms of ensuring equal access to rights such as education, employment and housing for migrants. In this article, we discuss a variety of approaches to defining and measuring integration and, drawing on the concluding observations of a number of UN human rights treaty monitoring bodies, argue in favour of a model of integration based on international human rights law. Indicators derived from this model are used to assess the extent to which policymaking in the public sector in Ireland is informed by human rights. Finally, it is suggested that the methodology used in this study could be applied outside the sphere of immigration and integration to other areas of public policy which directly affect individuals' human rights-from housing policy, to the provision of disability services, to early education and other important domains.
\end{abstract}

Keywords: integration; immigration; policy analysis

\section{Introduction}

Increasing levels of global migration have been accompanied by renewed discussions about the 'integration' of immigrants in the societies in which they live-raising questions about social cohesion, national identity, and the value of multicultural policies. The approach of public bodies towards migrant populations is often framed in terms of 'migrant integration'. However, integration policy and practice across Europe and beyond has proved ineffective in ensuring equal access to rights such as education, employment and housing for

* Clíodhna Murphy is a Lecturer in the Department of Law, and Mary Gilmartin is Professor in the Department of Geography, Maynooth University, Ireland. Leanne Caulfield is a Legal Researcher at the Law Reform Commission of Ireland. 
migrants (European Union FRA 2017; Alba and Foner 2015). Moreover, the concept of integration remains indeterminate. Some view the idea of integration as inherently negative and as representing a rejection of diversity by migrant-receiving societies (Guild 2004: 234). Current legal literature has documented the trend towards the conceptualization of integration as a mandatory obligation in immigration and citizenship law (Jesse 2017a; Wiesbrock 2009). At the same time, competing narratives centred on holistic, two-way paradigms of integration continue to emerge from NGOs, international organizations, and scholars (Ager and Strang 2008, 2010; Da Costa 2006).

In this article, we argue in favour of a human rights model of integration, based on international human rights law, and use indicators derived from this model to assess the extent to which integration policymaking in the public sector in Ireland is informed by human rights. The purpose of the human rights model put forward is twofold. First, it articulates what the concept of integration entails from a human rights perspective. Secondly, the indicators can be used as a practical analytical tool, to 'enable policy-makers to critically assess their policies towards migrants in light of international experiences and assess the effectiveness of different policy interventions' (Ruhs 2016: 322). Unlike some human rights indicators, they are not intended to be a scientific measure of how far the rights of migrants are respected and protected. Rather, they constitute markers of international best practice, as identified by the relevant UN treaty bodies.

Our analysis of the concluding observations on state reports of selected UN treaty monitoring bodies (the Human Rights Committee; the Committee on Economic, Social and Cultural Rights (CESCR); and the Committee on the Elimination of Racial Discrimination (CERD)) suggests that the normative goal of integration is the realization of migrants' human rights and their inclusion as equal members of society. The Committees highlight the positive duty of states to facilitate and encourage the process of integration by putting in place effective public policy measures and fostering an environment which promotes tolerance and diversity. Drawing on the approaches of these Committees, we find the key features of a human rights-based approach to integration to be: a commitment to the positive duty to eliminate discrimination; the active promotion of tolerance and respect for cultural and linguistic diversity; a rejection of the ideas of cultural assimilation and integration 'testing' of individuals; and the implementation and monitoring of practical integration measures to ensure equality of opportunity in respect of civil, political, social and economic rights.

In the opening part of the article, we introduce the various existing concepts and measurements of integration and make the case for a human rights-based approach. The second part describes how we use international human rights law as the basis for our integration model. The article then concludes by outlining how the indicators can be applied in practice, using the case study of Ireland. Ireland is a distinctive case study, due in part to the relatively recent nature of the emergence of immigration and integration issues and the resulting absence of a preconceived frame of analysis for integration.

\section{In favour of a human rights approach}

\subsection{Difficulties in defining and measuring integration}

The issue of migrant integration has received considerable academic and policy attention in recent years. However, 'integration' is a notoriously difficult idea to pin down, and the meaning and measurement of integration remain controversial. While integration was 
traditionally analysed in terms of exclusionary, assimilation and multicultural models, these frames of analysis have fallen out of favour (Murphy 2013a). Current scholarly studies of integration have focused on the ideas of 'civic citizenship' (Jesse 2017b) and 'settlement' (Bauder and Shields 2015) as alternative frames for thinking about integration and belonging. In the policy literature, there is a focus on integration as a two-way process. Definitions of integration used by the UN High Commissioner for Refugees (UNHCR) (Da Costa 2006), the European Union (EU)—within its Framework for the Integration of Third Country Nationals (Council of the EU 2004)—and the Council of Europe (Orton 2012) emphasize the multidimensional nature of integration involving a two-way process of adaptation. Overall, if one examines the academic and policy literature as well as state practice, 'it is possible to distil two potentially opposing approaches to migrant integration' (Thym 2016: 90). At one end of the spectrum is an approach which considers 'equal rights as an end in itself irrespective of the actual degree of social integration', while at the other is an approach which 'focuses on social interaction on the ground regarding questions such as knowledge of the local language, civic tests, labour market participation or other criteria' (ibid.).

Debates about the meaning of integration have included some discussion of the role of law in this social process (Groenendijk 2006). Recent research has examined the emergence of 'civic integration' by way of integration testing in domestic immigration and citizenship law (Jesse 2017a; Bonjour 2014; Kostakopoulou 2010). The civic integration model, some argue, relies on an artificially constructed national cultural and linguistic identity into which migrants are expected to integrate (Carrera 2009; van Oers et al. 2010). Moreover, it conceptualizes integration as an individual obligation of the migrant and fails to recognize that it is 'the receiving society which dictates the terms and conditions that will determine how immigrants can live in that society' (Jesse 2017b: 361).

Another strand of the legal literature emphasizes the significance of the supranational dimensions of the concept of migrant integration. Jesse confirms the important influence of EU law and policy, while Thym has charted the theoretical underpinnings of the approach of the European Court of Justice to integration (Jesse 2017a; Thym 2016). Xanthaki has studied in detail the contribution of the international human rights forums, and Murphy has critiqued the evolving concept of integration in the case law of the European Court of Human Rights (Xanthaki 2010, 2016; Murphy 2017). The research has highlighted the particular difficulties for courts in assessing integration in an adversarial and individualized setting, and in developing a coherent approach to the requirements of societal membership (Murphy 2017; Dembour 2015).

In addition to the variety of understandings of integration put forward in policy, scholarly and legal circles, there have been numerous attempts to provide a common measure of migrant integration across EU and OECD member states. The Zaragoza indicators measure integration outcomes in terms of employment, health, education, social inclusion and active citizenship, and these indicators have been augmented or further developed by the European Commission's Directorate-General for Migration and Home Affairs (Huddleston et al. 2013). Similarly, the OECD has developed integration indicators grouped into integration 'areas' such as participation in the labour market, housing, and civic participation/ social cohesion (OECD 2012; OECD/EU 2015). The Migrant Integration Policy Index (MIPEX) comprises an assessment of the integration policies of 38 countries, using policy indicators which are categorized under eight policy areas, including for example access to nationality, family reunion and labour market mobility. MIPEX draws on Council of 
Europe conventions, EU Directives and international conventions, as well as Europe-wide policy recommendations (MIPEX 2015). In the refugee-specific context, UNHCR has developed an Integration Evaluation Tool (IET), specifically designed for refugees, with indicators covering legal, socioeconomic, and sociocultural domains (Migration Policy Group 2016). In its development of general migrants' rights indicators, the Global Knowledge Partnership on Migration and Development (KNOMAD) argues that the fulfilment of migrants' rights is an essential tool for social integration in multicultural societies, and that migrants' rights indicators promote evidence-based policymaking (Ceriani Cernadas et al. 2015).

The principal criticisms of EU and national integration policies have been that they have co-opted the idea of integration as part of a shift in favour of cultural assimilation and/or as a tool of immigration control (Mullally 2013: 911; Carrera 2009). Given this, current measurements of integration, which focus primarily on outcomes, are insufficient for the purposes of understanding how to develop effective and participatory integration policies. They do not track progress towards these outcomes, nor do they adequately identify the objectives which should inform state policy on integration. As a consequence, they miss opportunities for intervention directed at 'full participation and integration of migrants' (UN CERD 2015: 6). Integration must be reclaimed as a long-term process, the normative goal of which is the full realization of the human rights of migrants on an equal basis with existing members of society (Murphy 2013a, 2013b; Xanthaki 2010, 2016). The legal basis for this human rights-based paradigm can be found in the international human rights instruments.

\subsection{The case for a human rights-based approach}

The European Commission's recent review of policy and research on migration acknowledges that 'integration remains a challenge' across Europe (King and Lulle 2016). In the Irish context, the UN Human Rights Committee, the UN Committee on the Elimination of Racial Discrimination (CERD Committee), and the UN Committee on Economic, Social and Cultural Rights (CESCR) (among others) have all recently identified serious gaps in human rights protections for migrants living in the state (UN Human Rights Committee 2014c; UN CESCR 2015a; UN CERD 2011). In its concluding observations on Ireland's state report in 2015, the CESCR commented:

The Committee is concerned at the increase in the number of people living in consistent poverty or at risk of poverty, particularly among children, single-parent families, older persons, persons with disabilities, migrants, Travellers and Roma. It is also concerned at the lack of integration of economic, social and cultural rights into poverty reduction policies as well as at the absence of concrete policies addressing the specific needs of the groups affected. (UN CESCR 2015a: 7)

This reflects the type of commentary frequently adopted by the Committees in their concluding observations in respect of migrant-receiving countries. Indeed, the UN Special Rapporteur on the human rights of migrants, François Crépeau, exhorted the European Union to develop a 'human rights-based framework for migration', which would involve a 'fundamental rethinking of the conceptualization of migrants and the development of integration programmes within the context of general diversity policies' (UN Human Rights Council 2015).

Yet rather than addressing the ineffectiveness of their policy and practice, states often seek to shift the focus towards imposing a duty on migrants to conform to existing and 
perceived 'national values' (EU FRA 2017). The EU policy framework on integration, for example, has been criticized for its growing focus in this regard (Carrera 2009). This reflects the increasing trend across EU member states, mentioned above, to use integration tests as a tool of immigration control and as a condition of family reunification and naturalization. For example, in the UK, applicants are required to pass a 'Life in the UK' test in order to obtain indefinite leave to remain and citizenship (Ryan 2008; Kostakopoulou 2010). In France, the Netherlands and Denmark (among other countries), pre-departure integration examinations are imposed on those seeking access to family reunification (Bonjour 2010; Jesse 2017a). In these ways, as Xanthaki argues, 'integration is used as a smokescreen to weaken human rights obligations in Europe' (Xanthaki 2016: 816).

A human rights-based approach offers an antidote to both the problem of effectiveness and that of defining appropriate aims for integration policy. It will be shown below that a human rights approach requires the elaboration of specific integration policies in order to ensure that migrant populations can in practice access fundamental human rights such as housing, education, health care and employment. Moreover, the idea of imposed integration testing is problematic from a human rights perspective, and the analysis of the CERD Committee is robust in this regard. Indeed, the prohibition of assimilation is a wellestablished feature of many human rights instruments, as is the spirit of multiculturalism (Xanthaki 2010).

Finally, there are persuasive legal reasons for employing a human rights approach. It would clearly help to ensure that the state is in full compliance with its legal obligations in international human rights law. Moreover, in Ireland where this research was based, as in some other countries, public bodies are now required to apply a human rights and equality lens to their policies and practices under the legislative human rights and equality 'public sector duty' (Section 42(1) of the Irish Human Rights and Equality Commission Act 2014). These legal dimensions are more fully discussed in the next section.

\section{Deriving a human rights model from international human rights law}

\subsection{Why start from international human rights law?}

We use the concept of integration articulated by the UN human rights treaty monitoring bodies as a model of best practice against which to assess integration policies. There are theoretical, legal, and practical justifications for this use of international human rights law. First, looking to the international and supranational elements of integration could provide an escape route from the politics of identity inherent in considering integration solely in the context of the nation state, which is at the root of the twin national trends towards perceiving integration as primarily linked to identity and enshrining integration conditions in immigration legislation (Ward 2002: 219). In order to refocus the debate in a more human rights-oriented direction, there is a need to move beyond the national context and to develop a wider conceptual framework for discussing integration. One way to refocus integration policy and practice on social inclusion and equalization of opportunity is to insist on the recognition of the concepts of integration under construction by international human rights actors.

From the legal perspective, the international human rights treaties provide the foundation for an equality-based paradigm of integration, by generally requiring state parties to provide the rights enshrined therein to all persons on their territory without discrimination on the basis of nationality, race, religion or immigration status. This also links in to a more 
abstract point: international human rights law involves a reshaping of the relationship between the state and persons within its jurisdiction (Bhabha 2005: 42). By accepting human rights duties which transcend it, the state loses a degree of control over the treatment of immigrants and non-citizens, such that it is no longer permitted to treat immigrants within its jurisdiction in ways which are contrary to its obligations under international human rights law. Through the engagement of supranational norms, the importance of the distinction between the individual as citizen and as foreigner, which is so central to the notion of state sovereignty as well as to national integration policies, begins to be broken down (Guild 2005: 108). Integration paradigms which are based on narrow conceptions of national identity and a strict dichotomy between the citizen and others are thus put under significant pressure by international human rights norms.

Aside from the state's international legal obligations and the universal nature of international human rights law, there are also more tangible ways in which an international human rights law approach 'adds value' to the analysis. Existing research shows that the UN human rights treaty monitoring bodies are, in their concluding observations on state reports, developing a nascent conception of integration which centres on a two-way, noncoercive process of the progressive realization of equality for migrants (Murphy 2013b). This fledgling integration model emerging from the work of the UN treaty monitoring bodies provides a useful, to some extent ready-made, framework for thinking about integration-and one which is firmly rooted in human rights.

Within the Council of Europe framework, the European Convention on Human Rights (ECHR) applies to all persons in the jurisdiction of contracting states (Article 1), thus clearly applying in principle to migrants. The European Court of Human Rights (ECtHR) has considered integration issues primarily in the context of its Article 8 case law on the expulsion of and family reunification for non-citizens (see e.g. Üner $v$. The Netherlands (2006)). In this groundbreaking jurisprudence, the Court has confirmed that integration or social ties to the 'host state' will lead to enhanced protection against expulsion for noncitizens under Article 8. However, scholars have pointed out that the Court's jurisprudence in this area has been somewhat arbitrary and unpredictable (Steinorth 2008; Thym 2014; Murphy 2017). Moreover, the conception of integration employed by the ECtHR in its jurisprudence is problematic, with one of the central focuses of the Court an examination of whether the individual has cut all ties to the country of nationality (Murphy 2017). The Court's judgments in these Article 8 cases do not usually enter into a discussion of the state's role in contributing to a person's integration. The limited context in which the concept of integration is being developed by the ECtHR (that is, the proposed expulsion of an individual), along with the problems associated with the one-sided nature of the concept employed by the Court, means that overall the normative concept of integration under construction by the ECtHR is less useful, in terms of developing a best practice human rights model for policy analysis, than that within the universal treaty regime.

\subsection{The role of national and regional human rights and equality legislation}

The full implications (and justiciability) of the legislative public sector duty, in both its Irish and UK versions, are yet to be fully worked out (see McColgan 2015; Fredman 2011). Nonetheless, in the Irish context, the Irish Human Rights and Equality Commission Act 2014 requires public bodies to apply a human rights and equality lens to their activities. Section 42(1) of the Act provides: 
A public body shall, in the performance of its functions, have regard to the need to-

(a) eliminate discrimination,

(b) promote equality of opportunity and treatment of its staff and the persons to whom it provides services, and

(c) protect the human rights of its members, staff and the persons to whom it provides services.

Fredman notes (in the UK context) that 'without a duty to take action, the risk of proceduralism is difficult to overcome' and it may be difficult to achieve substantive equality under this type of approach (Fredman 2011: 427). However, the duty clearly applies to the policies adopted by public bodies, and section 42 of the Irish Human Rights and Equality Commission Act 2014 gives some further guidance in this regard. In preparing strategic plans, public sector bodies must assess and identify the human rights and equality issues that are relevant to their functions. These issues must relate to all of their functions as policymaker, employer and service provider. Public bodies must then identify the policies and practices that they have in place or that they plan to put in place to address these issues. Finally, in their annual reports, or equivalent documents, public bodies must report in a manner accessible to the public on developments and achievements in that regard. It thus seems that public bodies are required to assess how the human rights of migrants are specifically affected by their functions and to put in place policies to address any shortcomings or barriers.

The EU has a developed legal human rights architecture, including the Charter of Fundamental Rights (Peers et al. 2014) and extensive non-discrimination legislation (Ellis and Watson 2012). It has also adopted Directives on international protection and legal migration which explicitly allow for member states to impose integration measures and conditions in certain circumstances (Jesse 2017b). The implementation of these Directives has spawned a body of case law imposing limits on member states' discretion to use integration conditions as part of national immigration legislation (Thym 2016; Jesse 2016, 2017a; Dąbrowska-Kłosińska 2018). We do not use EU law as a cornerstone of our human rights model, for a number of reasons. First, its binding application is limited to EU member states. Secondly, among EU member states, Ireland and the UK have not opted into the majority of the Directives on legal migration, and neither do these legal measures apply to Denmark (EU FRA 2014: 262). This means that EU law does not directly apply in these areas for these countries. Finally, the Court of Justice of the EU has expressly addressed questions of social integration for non-EU nationals only in the context of interpreting member states' implementation of EU migration law. It has not considered in detail the positive obligation of states to create an environment that facilitates the realization of migrants' human rights through integration, unlike the UN treaty bodies.

\section{The specific elements of a human rights approach}

Our model builds on the development of the concept of integration by the treaty bodies established under the International Covenant on Civil and Political Rights (ICCPR), the International Covenant on Economic, Social and Cultural Rights (ICESCR) and the International Convention on the Elimination of All forms of Racial Discrimination (ICERD) (Murphy 2013a, 2013b). As mentioned already, the principles of nondiscrimination and equality, which form the dominant philosophical thread running through the treaties (McColgan 2003), constitute the foundation of a human rights-based integration paradigm. 
The principal rationale for the selection of these particular instruments for guidance on best practice on integration is one of universality - the ICCPR and the ICESCR apply to all persons in state parties and thus apply to all migrants in those states. In addition, ICERD applies to all victims of racial discrimination, which is very widely defined in Article 5 as 'any distinction, exclusion, restriction or preference based on race, colour, descent, or national or ethnic origin', and so applies to all non-citizen migrants. These treaties are widely ratified, including by all EU member states, albeit with some interpretive declarations and reservations. ${ }^{1}$

The examination of the development of the concept of integration in the work of these UN treaty monitoring bodies (the Human Rights Committee, the CESCR, and the CERD Committee) was conducted primarily through an analysis of their concluding observations on state reports published up to December 2017. These observations often expressly mention integration-related issues and the concept of integration. While concluding observations are generally not understood as having legally binding effect, nevertheless, as outputs of a treaty body, they have a 'notable authority, albeit unspecified', in particular where they purport to interpret treaty provisions (O'Flaherty 2006). In this way, unlike other human rights indicators, our indicators do not seek to monitor formal legal compliance with international human rights treaties; rather, they represent markers of international best practice as identified by the treaty monitoring bodies.

The development of human rights indicators generally 'requires linking these indicators with the provisions of international human rights treaties' (de Beco 2013: 382), as has been done in respect of the rights to water, education, and health, for example (Meier et al 2014; Tomaševski 2006; de Beco 2013; Hunt and MacNaughton 2007). However, this is problematic in the context of developing human rights indicators for examining integration policy given that integration is not mentioned in the text of the treaties. Similarly, while the Human Rights Committee and the CERD Committee have the competence to consider individual complaints, the views of the Human Rights Committee on individual complaints have not to date specifically referred to the concept of integration, and the individual complaints procedure under the ICERD is rarely used. The general comments or recommendations of each of the three bodies examined in this study have some useful information on the rights of non-citizens and the principle of non-discrimination (Murphy 2013b: 168), but again there is little in the general comments which directly addresses integration policy. In contrast, integration-related issues as well as the concept of integration itself are often expressly referred to by the Committees in their concluding observations on states parties' reports.

The next sections will show that the common thread in the work of the three bodies discussed is the emphasis on the protection of the human rights of migrants and the creation of equal opportunities through rights protection. The importance of putting in place policies which are actually effective in their aim to include migrants as equal members of society is also underlined. At the end of each of the following two sections we include a table (Tables 1 and 2) to summarize the key features of the approaches taken by the Committees under the headings 'structural issues' (that is, the substantive approach taken to the concept of integration), and 'process and outcomes' (that is, the process by which this substantive concept can be realized, and how outcomes can be monitored).

1 For information on ratifications and reservations by states, see UN Treaty Body Database (https:// tbinternet.ohchr.org/_layouts/15/TreatyBodyExternal/Treaty.aspx). 


\subsection{Human Rights Committee and Committee on Economic, Social and Cultural Rights}

While the Human Rights Committee and the CESCR refer to integration-related matters they rarely do so under the banner of 'integration', and integration in itself is evidently not among the primary concerns of these Committees. Despite this, the Human Rights Committee and the CESCR make many observations which are related (even if for the most part indirectly) to integration. Integration issues are closely linked to equality and non-discrimination and encompass legal, social and cultural dimensions involving a wide range of human rights, including the right to family life, freedom of religion, housing, health care, and education. The Human Rights Committee in particular frequently comments on integration-related issues, even if it does not always expressly refer to integration. These issues include family reunification, freedom of religion, and discrimination, xenophobia and racism (see e.g. UN Human Rights Committee 2004 (Belgium), 2009b (Switzerland), 2009a (Sweden)).

The non-discrimination guarantees contained in Articles 2 and 26 of the ICCPR have formed the basis for many of the concerns expressed by the Human Rights Committee relating to the treatment of migrants. Most notably, the Committee regularly points out the existence of anti-immigrant sentiment and discrimination in state parties and recommends that states do more to eradicate these problems and promote intercultural understanding. In 2014, for example, it stated that Malta should strengthen its efforts to eradicate stereotypes and discrimination against migrants, inter alia, by conducting public awareness campaigns to promote tolerance and respect for diversity (UN Human Rights Committee 2014d: para. 9). The Committee has also criticized states in relation to discrimination faced by migrants in accessing public services. In respect of Spain, it observed that immigrants, foreigners and ethnic minorities continue to be subjected to discrimination in access to housing, education, employment and health care (UN Human Rights Committee 2015: para. 9). Likewise, in 2016, while acknowledging Sweden's efforts to integrate newly arrived migrants into the labour market, it stated that the state party should ensure that vulnerable Roma migrants enjoy equal rights without discrimination and identify ways to facilitate their access to support assistance services, including social benefits (UN Human Rights Committee 2016: paras 32, 15). Language-based discrimination is another important issue for the Committee. For example, it found in 2014 that non-Latvian speakers face language-based discrimination in terms of access to public services and stated that Latvia should 'enhance its efforts to ensure the full enjoyment of the rights in the Covenant by "non-citizen" residents and members of linguistic minorities, and further facilitate their integration into society' (UN Human Rights Committee 2014a: para.7).

Similarly, discrimination is a central focus of the CESCR, which consistently refers to inequalities experienced by immigrants and members of ethnic minorities in accessing rights relating to housing, employment, health care and education (see e.g. UN CESCR 2009a (Cyprus), 2009c (Republic of Korea), 2009b (United Kingdom), 2006a (Liechtenstein), 2013a (Denmark), 2013b (Belgium). In 2015, it voiced its concern about the persistent discrimination against persons with immigrant backgrounds and Roma in Greece, particularly in employment, education, health care and housing (UN CESCR 2015b: para. 9; see similar comments in e.g. UN Human Rights Committee 2014b (USA): para. 14). The CESCR has expressed particular concerns regarding the labour conditions of migrants. For example, it has suggested that the working conditions of migrants in Slovenia are characterized by low income and unlawful deductions, wage arrears, extra working hours without compensation, short-term contracts and subcontracting, lack of social benefits for workers in the 
informal economy, and limited access to justice (UN CESCR 2014b: para. 17). In its most recent concluding observations issued to the United Kingdom (UK), the Committee was troubled by the 'persistent discrimination' against migrant workers in the labour market, and the high and increasing concentration of migrant workers in low-paid work. The UK was asked (among other things) to improve the complaint mechanisms and legal assistance provided to migrant workers (UN CESCR 2016: paras 34, 35).

For the Human Rights Committee and the CESCR, integration policy forms part of the more general positive obligation of states to eliminate discrimination. In particular, the framing of integration by the Human Rights Committee in its concluding observations mainly in terms of equality under Articles 2 and 26 rather than in terms of the minority protection provided in Article 27 signals a broad-based conception of integration as the progressive realization of equality between existing and immigrant populations (rather than centring on a narrow culture-based core). Overall, the Human Rights Committee and the CESCR construct integration as a long-term and multifaceted process, involving legal, social and cultural dimensions, rather than a process of cultural assimilation to be undergone by newly arrived migrants. This conclusion is reinforced by the strong preference of both Committees for an intercultural approach to diversity. The CESCR, in particular, consistently advocates for state parties to intensify their efforts to create a culture of tolerance and respect for cultural diversity (UN CESCR 2000 (Portugal): para. 18; 2004 (Spain): para. 25; 2008 (Sweden): para. 16; 2006b (Former Yugoslav Republic of Macedonia): para. 48; 2018 (Mexico): para. 67). and highlights the importance of programmes to promote multiculturalism and the recognition of cultural difference (UN CESCR 1993 (Australia): para. 5) (Table 1).

Table 1. Key aspects of approaches of Human Rights Committee and CESCR

\begin{tabular}{|c|c|}
\hline Structural issues & Process and outcomes \\
\hline Equality-based & Long-term and multifaceted process \\
\hline $\begin{array}{l}\text { Legal, social and cultural dimensions involving a } \\
\text { wide range of human rights, including the right } \\
\text { to family life, freedom of religion, housing, } \\
\text { health care, and education }\end{array}$ & $\begin{array}{l}\text { Integration policy forms part of more general } \\
\text { obligation to eliminate discrimination }\end{array}$ \\
\hline $\begin{array}{l}\text { Built on a foundation of tolerance and acceptance } \\
\text { of diversity }\end{array}$ & \\
\hline
\end{tabular}

\subsection{CERD Committee}

The CERD Committee has been particularly robust in reminding states, in its General Recommendation on discrimination against non-citizens, that 'although some rights, such as the right to participate in elections, to vote and to stand for election, may be confined to citizens, human rights are, in principle, to be enjoyed by all persons' (UN CERD 2004: para. 3). In particular, the Committee confirms that states parties must '[r]emove obstacles that prevent the enjoyment of economic, social and cultural rights by non-citizens, notably in the areas of education, housing, employment and health' (ibid: para. 29). The Committee further reminds states of their positive obligations to take the necessary measures to allow non-citizens to preserve and develop their cultural identity (ibid: para. 37). The Committee clearly expressed its preference for a human rights-based model when it congratulated Portugal in January 2017 on its human rights-based migrant integration 
policies and also on the 'one-stop-shop' model of service provision applied for migrants regardless of their legal status (UN CERD 2017: para. 6). A participatory approach to integration policy is advocated in the concluding observations and the Committee has encouraged states parties 'to ensure the participation of [national or ethnic minorities] in the design and implementation of integration policies and programmes, at both national and local levels' (UN CERD 2008 (Namibia): para. 24).

The CERD Committee conceives of integration in terms of an objective in itself, which constitutes a positive obligation on states. A relatively nuanced conception of integration is under construction in its concluding observations. The basic approach of the CERD Committee is that states are required to ensure that effective measures to facilitate the integration of minority groups (including immigrants) are put into place. These measures may not constitute forced assimilation or segregation, and must respect the cultural identity of migrants. The Committee has specifically noted that integration policies must 'respect and protect the cultural identities of persons belonging to national or ethnic minorities within its territory' (see UN CERD 2008 (Namibia): para. 24). It has further highlighted that well intentioned measures should not have as a side effect an 'assimilationist effect that leads to the loss of cultural identities by those affected' (UN CERD 2010 (Denmark)). The same preference for interculturalism which is evident in the work of the Human Rights Committee and the CESCR is expressed by the CERD Committee, which recommends that state parties should combat racial discrimination by seeking 'to promote understanding among racial and ethnic minority groups’ (UN CERD 2014c (USA): para. 25).

A two-way conception of integration is favoured by the Committee, whereby a balance is maintained, between the responsibilities of the receiving state and its existing communities on the one hand, and those of the migrant in the integration process on the other. It has also made more specific recommendations in relation to the role of political participation, access to nationality, the importance of labour market integration, and the protection of social and economic rights in the integration process (see e.g. UN CERD 2014b (Estonia); 2014a (Belgium); 2016 (Italy); 2009 (Poland).On the question of language acquisition, the importance of access to state language learning courses as an essential integration tool has been underlined. For example, the CERD Committee has recommended the provision of free-of-charge language courses for persons belonging to minorities and persons with undetermined citizenship (see UN CERD 2014b (Estonia): para. 9(b)). However, while the Committee views the acquisition of language as an important aspect of integration, it is wary of lack of proficiency in the state language being used as a barrier to naturalization (see UN CERD 2006 (Norway): para. 19).

With regard to the specific question of civic integration testing, the CERD Committee has stopped short of finding that these measures are legally unacceptable in principle, although it clearly considers that they could be discriminatory in effect and constitute a barrier to integration in practice. The Committee has noted that where integration measures result in the primary responsibility for integration being shifted away from the state and on to migrant individuals and communities, this 'puts migrants in particularly vulnerable situations at risk of receiving insufficient attention and support, leaves them vulnerable to social exclusion, and hampers their integration and the full enjoyment of rights' (UN CERD 2015 (Netherlands) para. 5) In respect of the Civic Integration Examination Abroad (a predeparture integration test) imposed on family migrants by the Netherlands, the Committee noted that citizens of certain countries are exempt from the procedure, while it is compulsory for citizens of other countries (ibid: para. 29). It was concerned that the requirement of the 
Civic Integration Examination Abroad poses a particular challenge for persons in vulnerable situations, such as women who have been deprived of accessing education, persons who are illiterate or persons using a different alphabet. The Committee also expressed its concern that the costs of the examination preparation pack and the course fees are particularly high and may severely hamper family reunification. The Netherlands was recommended to ensure that policies aimed at integration of migrants are not discriminatory in effect. The CERD Committee went as far as to encourage the discontinuation of the Civic Integration Examination Abroad and to allow all migrants to take integration tests on Dutch territory. In a similar vein, the UK-another country which has introduced integration requirements as part of immigration law-was warned by the Committee to examine the impact of integration policies 'to ensure that they do not result in indirect discrimination' (UN CERD 2014d: para. 14(a)). In relation to access to naturalization, the CERD Committee has expressed concern that economic integration criteria enshrined in Belgian nationality legislation create additional obstacles to the integration of migrants into Belgian society, especially for those who face difficulties in obtaining paid employment (UN CERD 2014a: paras 17, 18).

Finally, the Committee has emphasized the need to allocate resources to the development of integration policy, in order that integration policies are actually effective (UN CERD 2017 (Portugal), 2015 (Netherlands). In 2017, for example, the CERD Committee recommended that Portugal allocate sufficient resources to the national body in charge of integration in order to enable it to discharge its mandate efficiently (UN CERD 2017: para. 15).

Table 2. Key aspects of approach of CERD Committee

\begin{tabular}{lc}
\hline Structural issues & Process and outcomes \\
\hline $\begin{array}{l}\text { Integration an objective in itself, which constitutes a } \\
\text { positive obligation on states }\end{array}$ & $\begin{array}{c}\text { States required to put in place effective } \\
\text { integration policies }\end{array}$ \\
$\begin{array}{l}\text { Measures must respect the cultural identity of migrants } \\
\text { and avoid assimilation and segregation } \\
\text { Molitical participation, access to nationality, equal } \\
\text { the allocation of resources }\end{array}$ & \\
$\begin{array}{l}\text { protection of social and economic rights are some } \\
\text { examples of important aspects of the integration } \\
\text { process }\end{array}$ & \\
\end{tabular}

\subsection{Measuring and implementing human rights-based integration policy}

While the core UN treaty monitoring bodies require the effective implementation of integration policy, they provide little or no specific guidance on how this can be achieved. For this, it is necessary to turn to the related work of the Office of the UN High Commissioner for Human Rights (OHCHR). Following several years of research and consultation, the OHCHR has provided a guide to measurement and implementation of human rights norms generally (UN OHCHR 2012). In particular, it has designed 'process indicators' which help in assessing a state's efforts, through its implementation of policy measures and programmes of action, to transform its human rights commitments into the desired results. Some common process indicators are: indicators based on budget allocations; coverage of targeted population groups under public programmes; incentive and awareness measures extended by the duty bearer to address specific human rights issues; and indicators 
reflecting functioning of specific institutions (for example, national human rights institutions). Outcome indicators help in assessing the results of state efforts in furthering the enjoyment of human rights. We drew on the OHCHR guidelines in the development of process and outcomes human rights indicators for integration policy.

\section{Human rights indicators}

Our analysis of the concept of integration developed by the UN treaty bodies suggests that the essence of integration lies in immigrants, and their descendants, progressively achieving equal treatment and outcomes as existing members of society. This model is based on individual equality, interculturalism, and state responsibility for social inclusion. The treaty bodies consistently emphasize the legal responsibility of states to facilitate and encourage this process by putting in place effective public policy measures.

Drawing on the approach of international human rights treaty monitoring bodies, as well as the public sector duty set out in section 42 of the Irish Human Rights and Equality Commission Act 2014, the central elements of a human rights-based approach to integration are:

1. a commitment to the positive duty to eliminate discrimination (including the elaboration of integration policy and the allocation of resources);

2. the active promotion of tolerance and respect for cultural and linguistic diversity;

3. a rejection of the ideas of (i) cultural assimilation, (ii) a one-sided notion of integration which places the onus of 'integration' primarily on the individual, and (iii) integration 'testing' of individuals;

4. the implementation and monitoring of practical integration measures to ensure equality of opportunity in respect of civil, political, social and economic rights, for all people resident in the state.

From our review of the law, the outputs of the treaty bodies, and the literature, we concluded that a human rights and equality perspective in integration policies could be assessed with reference to structural issues, process and outcomes (borrowing the typology of the OHCHR indicators, but adapting the meaning of these domains as outlined in Section 3 above). We identified the following key features of good practice (Table 3).

Table 3. Human rights and equality indicators of good practice in integration policies

\section{Structural}

The policy expressly identifies measures aimed at eliminating discrimination

The policy expressly addresses human rights

The policy identifies practical measures that promote equal access to these human rights

The policy expressly refers to respect for cultural, linguistic or other forms of diversity

Process

The policy is being implemented, with specific budget/staff allocations

The policy provides for sufficient coverage of target populations

The policy is being mainstreamed

\section{Outcomes}

It is clear how, and by whom, the effectiveness of the policy is being measured

The success of the policy is addressed in the annual report

The annual report provides for follow-up 


\section{Applying the human rights model to Irish integration policy: a case study snapshot}

Integration policy in Ireland has evolved in a largely piecemeal fashion. An initial flurry of activity culminated in 2008 with the publication of the first formal strategy for integration, Migration Nation (Office of the Minister for Integration 2008). However, the advent of the economic and financial crisis in 2008 diverted attention and resources from migrant integration. There was no meaningful policy development between then and 2017, when the second overarching integration document, the Migrant Integration Strategy, was published (Department of Justice and Equality 2017). At the same time, the introduction of the public sector duty in 2014 has created the clear possibility for the development of integration policy that is informed by a human rights perspective. With this in mind, the aim of our research was to develop a workable set of indicators which could be used to both assess and develop public policy on integration from a human rights perspective.

Given our identification of best practice indicators in Table 3, our first objective was to conduct an audit of the integration policies of public bodies in Ireland. This involved writing to 432 public bodies requesting a copy of their integration and/or diversity policy or strategy documents. One hundred and fifteen relevant documents were received from 76 public bodies, and we reviewed these policies using the human rights indicators outlined above. We also carried out interviews with a small sample of public bodies whose integration policies provided examples of good practice. The detailed results of the study were compiled in a report which was made available to public bodies (Murphy et al. 2017) and we set out some key findings below. Overall, we found that Irish public integration policy falls short of the best practice model outlined above in previous sections. Integration policy is underdeveloped across the public sector and most bodies do not appear to have specific integration policies in place. Where policies exist, they are not explicitly informed by human rights principles and do not refer to specific human rights challenges faced by migrant populations. In particular, our research shows that, among public bodies in Ireland, there is a clear need for greater understanding of the positive duty to promote and protect the human rights of migrants and also of how that might translate into specific actions for the particular body in question.

\subsection{Analysis of the national Migrant Integration Strategy}

The starting point for the policy evaluation stage of the research was the Migrant Integration Strategy, and our analysis of that document provides a good example of how the indicators can be applied as a means to critically assess public integration policy and identify human rights gaps.

One of the core elements of the Strategy's vision is that 'the basic values of Irish society are respected by all'. It also states that integration recognizes the right of migrants to give expression to their own culture in a manner that does not conflict with the 'basic values of Irish society', thereby placing an emphasis on the need for migrants to conform to Irish values without elaborating on what these values are. 'Human rights' are not expressly mentioned apart from a handful of references made in the context of describing the role of the Irish Human Rights and Equality Commission and the public sector duty. There are no references to upholding human rights standards or ensuring that human rights are enjoyed by all, and human rights principles are not expressly given as a rationale for any of the measures outlined in the document. There are a small number of express references to 
'equality' and equality principles. The Strategy aims to enable migrants or persons of migrant origin to participate 'on an equal basis' with those of Irish heritage and also expresses a commitment to ensuring 'equality of opportunity' for second generation migrants although it does not explain how this will be achieved. The document contains some implicit references to human rights and equality principles: the principle of non-discrimination is referred to implicitly in the outline of measures aimed at combating racism and xenophobia including intercultural training, ensuring representation of migrants on joint-policing committees (a forum to support co-operation between police, local authority officials, elected representatives and the community and voluntary sectors), and other measures.

With regard to implementation, the Strategy identifies two types of actions. The first type of actions are those applicable to all government departments, and include making information available through signs and translated material, training on intercultural awareness, and providing information on how to make a complaint about racist behaviour. The second type of actions are those which are intended to address particular issues. Some of these are quite specific - such as the inclusion of a target of one per cent for the employment of migrants from the European Economic Area (EEA) and people from minority ethnic communities in the civil service (in most cases civil service employment is not open to non-EEA nationals) and the monitoring of current school enrolment policies over time to assess their impact on the enrolment of migrant students. Other actions are broad and nebulous (for example, 'encourage businesses to focus on integration', and 'migrants will be encouraged to participate in local and national politics to the extent that these areas are legally open to them'). Finally, while the document makes some reference to a limited funding programme which is open to certain bodies, provisions regarding resources and information support to assist public bodies with implementing the actions are lacking. The Strategy provides that a mechanism will be introduced in order to assess the progress of the measures outlined therein (and subsequently the Migrant Integration Strategy Monitoring and Coordination Committee was established).

Viewed through the lens of the human rights model which underpins our research, the Migrant Integration Strategy demonstrates several positive features. The first of these positive points is that aside from some limited and under-explored references to 'values', the Strategy does not appear to focus on 'cultural integration'. It states that migrants should be enabled to celebrate their national, ethnic, cultural and religious identities (subject to the law). A second aspect is its participatory conception of integration: its stated vision is that migrants are facilitated to play a full role in Irish society. In addition, the Strategy is wide-ranging and includes some practical actions to address some long-standing problems in immigration law which can act as a barrier to accessing rights in practice (for example, a statutory scheme for long-term residency will be introduced (action 11) and the introduction of measures to enable registration of non-EEA migrants aged under 16 years (action 14)). Related to this, the Department of Social Protection is to continue to take measures to ensure that the Habitual Residence Condition for welfare payments is applied correctly and consistently (action 21).

While the Migrant Integration Strategy has strengths from a human rights and equality perspective, there are also some points which cause concern. An initial point of concern is that the strategic vision includes, as its first priority, that 'the basic values of Irish society are respected by all' and that it does not identify what these values are or might include. A second issue is that, as mentioned above, there are no express references to human rights principles as such, despite some vague references to 'equality of opportunity'. The 
Strategy's commitment to examine the imposition of a citizenship and/or language tests (action 12) is a further point of concern, given that these have not been a feature of Irish immigration and citizenship law to date and the CERD Committee has found that this type of testing potentially undermines integration in practice. Finally, the exclusion of asylum seekers and undocumented migrants from the scope of the policy is disappointing given the approach of the international treaty bodies that asylum seekers and undocumented migrants are also bearers of human rights (see e.g. UN CESCR 2014a (Romania): para. 12 (labour market integration of asylum seekers); UN CESCR 2016 (UK): para. 55 (access to health care for undocumented migrants); UN Human Rights Committee 2014b (USA): paras 15, 17 and 18 (access to health care, access to justice, working conditions of undocumented migrants).

\subsection{Evaluation of integration policies across the public sector}

Moving on from the national integration strategy, our full audit and evaluation of the integration policies of public bodies in Ireland clearly demonstrated that integration policies and measures are not yet being mainstreamed in the work of all public bodies. There were some encouraging findings, including the lack of negative or assimilationist references to integration and human rights, and the existence of examples of good policy and practice in some public bodies. However, we found integration policy to be generally underdeveloped in the public sector in Ireland. The majority of the documents (69 per cent) provided by public bodies were general 'Dignity at Work' or 'Inclusion and Diversity' policies which discuss inclusion and diversity in relatively vague terms and have a strong focus on employee recruitment processes, with little reference to the incorporation of an equality, diversity and inclusion approach in the organization's operations generally. While many of the policies evaluated (63 per cent) contain commitments to respect and promote equality and diversity, only about half of these broad commitments (53 per cent) are matched by specifically identifying practical measures designed to achieve this. Moreover, less than one-third (30 per cent) of the relevant policies provide for specific measures to meet the needs or promote the interests of migrants, or measures to promote interculturalism. A striking outcome is that only five per cent of the public bodies which we contacted provided us with a policy or other document that explicitly mentioned migrant integration. Similarly, only six per cent of the policies evaluated referred to the national Migrant Integration Strategy, despite its 76 specific actions being 'owned' by organizations across the public sector.

A key finding was that integration policy in Ireland is not explicitly informed by human rights principles. The idea of 'human rights' is rarely referred to in the policies examined here (less than ten per cent). Similarly, specific human rights are almost never expressly identified. The right to the enjoyment of the highest attainable standard of physical and mental health and the right to equality are the only human rights which are explicitly referred to. Only three per cent of the bodies which responded showed an awareness or understanding of the public sector duty to eliminate discrimination, promote equality of opportunity and treatment of its staff and the persons to whom it provides services, and protect the human rights of its members, staff and the persons to whom it provides services. Despite the lack of express reference to human rights principles, a variety of human rights are referred to implicitly, in particular the right to equal treatment and freedom from discrimination.

The research also points to gaps in terms of practical implementation of existing policies. Less than 50 per cent of the policies studied identify a position or department of responsibility for ensuring the implementation of the policy, for example. It also appears that 
the formal evaluation of the success of integration policies is rare. An even smaller proportion of the policies (17 per cent) referred to a budget or resource allocation being available for the implementation of the policies. For the majority of the bodies, it is not possible to make any assessment of the success of their policies in allowing migrants to enjoy human rights. This is largely due to the vague nature of many of the policies and the lack of references to policy implementation measures which reflect human rights principles. These factors are compounded by the lack of policy evaluation or references to progress of policy implementation in the annual reports of most bodies, which makes it virtually impossible to assess the success of the policies in allowing migrants to enjoy human rights.

\subsection{Practical guidelines for public bodies}

Our second overarching objective was to provide practical guidelines for public bodies on how to develop integration policies from a human rights perspective. Our audit of policies and our follow-up interviews with 11 representatives from six public bodies suggest that there is a need for greater understanding of the positive duty to promote and protect human rights rather than just to prevent breaches of human rights, particularly with reference to integration. Our practical guidelines thus identified two broad ways in which human rights-based integration policies could be developed. The first involves centralized support for the development of integration policies across public sector bodies, including appropriate education and training programmes that emphasize the positive human rights obligation, the provision of practical resources and guidelines, and the establishment of round tables and forums that provide targeted assistance in policy development. The second involves reflection and action within individual public bodies. In particular, public bodies should develop integration policies that are of specific relevance to the work of the body and the needs of its stakeholders and that are clearly set out in care documents. Staff and other stakeholders should be enabled to play an active role in integration policy development, and mechanisms for policy review or evaluation should be clearly outlined and applied. From this, we then provided specific guidelines for human rights-based integration policy development, implementation and evaluation, drawing from the indicators of best practice, our audit of existing policies and our empirical investigation of the practice of policy development in public bodies. We disseminated these guidelines widely by making them openly accessible on our university website, by sending hard copies to key policymakers, and by organizing a public event at the headquarters of the Irish Human Rights and Equality Commission.

\section{Conclusion}

This article contributes to ongoing debates about the meaning of integration, and introduces an explicit human rights dimension to these debates by developing human rights indicators for the review of integration policies at the national level. While human rights indicators have been around since the 1990s, 'most human rights indicator sets have never been applied' (de Beco 2013: 383), probably due to their complexity and unwieldiness. The short snapshot of our findings presented above demonstrates the relative ease with which we were able to apply the human rights indicators to the policies received, and form conclusions on the normative basis and current state of Irish integration policy. The type of policy analysis outlined in this article is, by nature, limited. However, formal policy is of particular importance in the context of migrant integration as it provides the framework for the 
national 'public philosophy' of integration (Favell 2001). In addition, our engagement with Irish public bodies showed that workable human rights indicators and guidelines, such as those described here, can play an important role in prompting reflexive thinking within the public sector about the conceptual basis and future development of public policy and administrative practice.

Finally, the approach detailed in this article has resonance beyond the sphere of immigration and integration. At its core, a human rights approach requires public bodies to embrace a positive duty to proactively remove barriers to the attainment of substantive equality. Given this, we tentatively suggest that our methodology of drawing directly on the concluding observations of the UN treaty bodies could be applied to other areas of public policy which directly affect individuals' human rights-from housing policy, to the provision of disability services, to early education and other important domains. The research could provide a practical template for developing human rights indicators, specifically for policy analysis, drawing directly on international human rights law. This is of particular interest in countries, such as Ireland and the UK, which have enshrined a legal duty to embed human rights and equality principles into public sector policymaking.

\section{Funding}

This work was supported by the Irish Human Rights and Equality Commission.

\section{References}

Ager, A., and A. Strang. 2008. Understanding Integration: A Conceptual Framework. Journal of Refugee Studies 21(2): 166-91.

- 2010. Refugee Integration: Emerging Trends and Remaining Agendas. Journal of Refugee Studies 23(4): 589-607.

Alba, R., and N. Foner. 2015. Strangers No More: Immigration and the Challenges of Integration in North America and Western Europe. Princeton University Press.

Bauder, H., and J. Shields (eds). 2015. Immigrant Experiences in North America: Understanding Settlement and Integration. Toronto: Canadian Scholars' Press.

Bhabha, J. 2005. Rights Spillovers: The Impact of Migration on the Legal System of Western States. In E. Guild and J. Van Selm (eds), International Migration and Security: Opportunities and Challenges, pp. 28-50. Routledge.

Bonjour, S. 2010. Between Integration Provision and Selection Mechanism: Party Politics, Judicial Constraints, and the Making of French and Dutch Policies of Civic Integration Abroad. European Journal of Migration and Law 12(3): 299-318.

— 2014. The Transfer of Pre-Departure Integration Requirements for Family Migrants among Member States of the European Union. Comparative Migration Studies 2(2): 203-26.

Carrera, S. 2009. In Search of the Perfect Citizen? The Intersection between Integration, Immigration and Nationality in the EU. Leiden: Martinus Nijhoff.

Ceriani Cernadas, P., M. LeVoy, and L. Keith. 2015. Human Rights Indicators for Migrants and their Families. KNOMAD Working Paper 5. https://www.knomad.org/sites/default/files/201704/KNOMAD \%20Working\%20Paper\%205\%20Human\%20Rights\%20Indicators\%20for\% 20Migrants.pdf.

Charter of Fundamental Rights of the European Union, 26 October 2012.

Council of the European Union. 2004. Common Basic Principles for Immigrant Integration in the European Union. In Council Conclusions, Justice and Home Affairs, pp. 19-25. Document 
14615/04, Brussels, 19 November. Available online at https://ec.europa.eu/migrant-integration/ main-menu/eus-work/actions.

Dąbrowska-Kłosińska, P. 2018. The Right to Family Reunion vs Integration Conditions for Third-Country Nationals: The CJEU's Approach and the Road Not Taken. European Journal of Migration and Law 20(3): 251-88.

Da Costa, R. 2006. Rights of Refugees in the Context of Integration: Legal Standards and Recommendations. UNHCR Legal and Protection Policy Research Series. Geneva: UNHCR.

De Beco, G. 2013. Human Rights Indicators: From Theoretical Debate to Practical Application. Journal of Human Rights Practice 5(2): 380-97.

Dembour, M.-B. 2015. When Humans Become Migrants: Study of the European Court of Human Rights with an Inter-American Counterpoint. Oxford University Press.

Department of Justice and Equality 2017. The Migrant Integration Strategy: A Blueprint for the Future. Dublin. Available online at http://www.justice.ie/en/JELR/Migrant_Integration_ Strategy_English.pdf/Files/Migrant_Integration_Strategy_English.pdf.

Ellis, E., and P. Watson. 2012. EU Anti-Discrimination Law (2nd ed.). Oxford University Press.

European Convention on Human Rights (Convention for the Protection of Human Rights and Fundamental Freedoms), 4 November 1950 (entered into force 3 September 1953).

European Court of Human Rights. Üner $v$ The Netherlands, Application no. 46410/99, Grand Chamber judgment 18 October 2006.

European Union Agency for Fundamental Rights (FRA). 2014. Handbook on European Law relating to Asylum, Borders and Immigration.

—. 2017. Together in the EU: Promoting the Participation of Migrants and their Descendants.

Favell, A. 2001. Philosophies of Integration: Immigration and the Idea of Citizenship in France and Britain (2nd ed.). Palgrave Macmillan.

Fredman, S. 2011. The Public Sector Equality Duty. Industrial Law Journal 40(4): 405-27.

Groenendijk, K. 2006. Legal Concepts of Integration in EU Migration Law. European Journal of Migration and Law 6: 111-26.

Guild, E. 2004. The Legal Elements of European Identity: EU Citizenship and Migration Law. Kluwer Law International.

- 2005. Cultural and Social Identity: Immigrants and the Legal Expression of National Identity. In E. Guild and J. Van Selm (eds), International Migration and Security: Opportunities and Challenges, pp. 101-12. Routledge.

Huddleston, T., J. Niessen, and J. Dag Tjaden. 2013. Using EU Indicators of Immigrant Integration. Final Report for Directorate-General for Home Affairs. Luxembourg: Publications Office of the European Union.

Hunt, P., and G. MacNaughton. 2007. A Human Rights-Based Approach to Health Indicators. In M. Baderin and R. McCorquodale (eds), Economic, Social and Cultural Rights in Action, pp. 303-30. Oxford University Press.

International Covenant on Civil and Political Rights, 16 December 1966 (entered into force 23 March 1976).

International Covenant on Economic, Social and Cultural Rights, 16 December 1966 (entered into force 3 January 1976).

International Convention on the Elimination of All Forms of Racial Discrimination, 7 March 1966 (entered into force 4 January 1969).

Jesse, M. 2016. Integration Measures, Integration Exams, and Immigration Control: $P$ and $S$ and K and A. Common Market Law Review 53(4): 1065-87.

- 2017a. The Unlawfulness of Existing Pre-Departure Integration Conditions Applied in Family Reunification Scenarios: Urgent Need to Change National Laws in the European Union. International Journal of Migration and Border Studies 2(3): 274-88. 
2017b. The Civic Citizens of Europe: The Legal Potential for Immigrant Integration in the EU, Belgium, Germany and the United Kingdom. Leiden and Boston: Brill.

King, R., and A. Lulle. 2016. Research on Migration: Facing Realities and Managing Opportunities. Brussels: European Commission.

Kostakopoulou, D. 2010. The Anatomy of Civic Integration. Modern Law Review 73(6): 933-58.

McColgan, A. 2003. Principles of Equality and Protection from Discrimination in International Human Rights Law. European Human Rights Law Review (2): 157-75.

- 2015. Litigating the Public Sector Equality Duty: The Story So Far. Oxford Journal of Legal Studies 35(3): 453-85.

Meier, B. M., J. G. Kestenbaum, G. L. Kayser, U. Q. Amjad, and J. Bartram. 2014. Examining the Practice of Developing Human Rights Indicators to Facilitate Accountability for the Human Right to Water and Sanitation. Journal of Human Rights Practice 6(1): 159-81.

Migrant Integration Policy Index. 2015. How Countries are Promoting Integration of Immigrants. Available online at http://www.mipex.eu.

Migration Policy Group. 2016. Refugee Integration Tool. Available online at https://www.mig polgroup.com/_old/diversity-integration/refugee-integration-tool.

Mullally, S. 2013. Retreat from Multiculturalism: Community Cohesion, Civic Integration and the Disciplinary Politics of Gender. International Journal of Law in Context 9(3): 411-28.

Murphy, C. 2013a. Immigration, Integration and the Law: The Intersection of International, EU and Domestic Regimes. Farnham: Ashgate.

- 2013b. Towards a Human Rights-Based Paradigm of Integration? The Contribution of International Law. European Human Rights Law Review (2): 166-80.

- 2017. Membership without Naturalisation? The Limits of European Court of Human Rights Case Law on Residence Security and Equal Treatment. In D. Thym (ed.), Questioning EU Citizenship: Judges and the Limits of Free Movement and Solidarity in the EU, pp. 287-307. Oxford: Hart Publishing.

Murphy, C., L. Caulfield, and M. Gilmartin. 2017. Developing Integration Policy in the Public Sector: A Human Rights Approach. Maynooth University. Available online at https://www.may noothuniversity.ie/sites/default/files/assets/document/MU\%20Developing\%20Integration\%20Policy $\% 20$ in $\% 20$ the $\% 20$ Public $\% 20$ Sector $\% 20 F O R \% 20$ WEB_0.pdf.

OECD. 2012. Settling In: Indicators of Immigrant Integration 2012.

OECD/European Union. 2015. Indicators of Immigrant Integration 2015: Settling In.

Office of the Minister for Integration 2008. Migration Nation: Statement on Integration Strategy and Diversity Management. Dublin.

O'Flaherty, M. 2006. The Concluding Observations of United Nations Human Rights Treaty Bodies. Human Rights Law Review 6(1): 27-52.

Orton, A. 2012. Building Migrants' Belonging through Positive Interactions: A Guide for Policymakers and Practitioners. Strasbourg: Council of Europe.

Peers, S., T. Hervey, J. Kenner, and A. Ward. 2014. The EU Charter of Fundamental Rights: A Commentary. Oxford: Hart Publishing.

Ruhs, M. 2016. Protecting the Rights of Temporary Migrant Workers: Ideals Versus Reality. In J. Howe and R. Owens (eds), Temporary Labour Migration in the Global Era: The Regulatory Challenges, pp. 299-324. Oxford: Hart Publishing.

Ryan, B. 2008. Integration Requirements: A New Model in Migration Law. Journal of Immigration Asylum and Nationality Law 22(4): 303-16.

Steinorth, C. 2008. Üner v. The Netherlands: Expulsion of Long-Term Immigrants and the Right to Respect for Private and Family Life. Human Rights Law Review 8(1): 185-96.

Thym, D. 2014. Residence as De Facto Citizenship? Protection of Long-Term Residence under Article 8 ECHR. In R. Rubio-Marin (ed.), Human Rights and Immigration, pp. 106-44. Oxford University Press. 
2016. Towards a Contextual Conception of Social Integration in EU Immigration Law.

Comments on $P$ \& $S$ and $K$ \& A. European Journal of Migration and Law 89(18): 89-111.

Tomaševski, K. 2006. Human Rights Obligations in Education: The 4-A Scheme. Nijmegen: Wolf Legal Publishers.

UN CERD (Committee on the Elimination of Racial Discrimination). 2004. General Recommendation No. 30. Discrimination against Non-Citizens. CERD/C/64/Misc.11/rev.3.

- 2006. Concluding Observations: Norway. CERD/C/NOR/CO/18.

2008. Concluding Observations: Namibia. CERD/C/NAM/CO/12.

2009. Concluding Observations: Poland. CERD/C/POL/CO/19.

2010. Concluding Observations: Denmark. CERD/C/DNK/CO/18-19.

2011. Concluding Observations on the Combined Third and Fourth Periodic Reports of Ireland. CERD/C/IRL/CO/3-4.

- 2014a. Concluding Observations on the Sixteenth to Nineteenth Periodic Reports of Belgium. CERD/C/BEL/CO/16-19.

- 2014b. Concluding Observations on the Combined Tenth and Eleventh Periodic Reports of Estonia. CERD/C/EST/CO/10-11.

- 2014c Concluding Observations on the Combined Seventh to Ninth Periodic Reports of the United States of America. CERD/C/USA/CO/7-9.

2014d. Concluding Observations on the Combined Twenty-First to Twenty-Third Periodic Reports of the United Kingdom of Great Britain and Northern Ireland. $\mathrm{CERD} / \mathrm{C} / \mathrm{GBR} / \mathrm{CO} / 21-23$.

2015. Concluding Observations on the Combined Nineteenth to Twenty-First Periodic Reports of the Netherlands. CERD/C/NLD/CO/19-21.

- 2016. Concluding Observations on the Combined Nineteenth and Twentieth Periodic Reports of Italy. CERD/C/ITA/CO/19-20.

- 2017. Concluding Observations on the Fifteenth to Seventeenth Periodic Reports of Portugal. CERD/C/PRT/CO/15-17.

UN CESCR (Committee on Economic Social and Cultural Rights). 1993. Concluding Observations: Australia. E/C.12/1993/9.

- 2000. Concluding Observations: Portugal. E/C.12/1/Add.53.

- 2004. Concluding Observations: Spain. E/C.12/1/Add.99.

- 2006a. Concluding Observations: Liechtenstein. E/C.12/LIE/CO/1.

- 2006b. Concluding Observations: The Former Yugoslav Republic of Macedonia. E/C.12/MKD/CO/1.

. 2008. Concluding Observations: Sweden. E/C.12/SWE/CO/5.

. 2009a. Concluding Observations: Cyprus. E/C.12/CYP/CO/5.

- 2009b. Concluding Observations: United Kingdom. E/C.12/GBR/CO/5.

. 2009c. Concluding Observations: Republic of Korea. E/C.12/KOR/CO/3.

- 2013a. Concluding Observations on the Fifth Periodic Report of Denmark, adopted by the Committee at its Fiftieth Session (29 April-17 May 2013). E/C.12/DNK/CO/5.

- 2013b. Concluding Observations Concerning the Fourth Periodic Report of Belgium. E/C.12/BEL/CO/4.

- 2014a. Concluding Observations on the Combined Third to Fifth Periodic Reports of Romania. E/C.12/ROU/CO/3-5.

. 2014b. Concluding Observations on the Second Periodic Report of Slovenia. E/C.12/ $\mathrm{SVN} / \mathrm{CO} / 2$.

- 2015a. Concluding Observations on the Third Periodic Report of Ireland. E/C.12/ $\mathrm{IRL} / \mathrm{CO} / 3$.

- 2015b. Concluding Observations on the Second Periodic Report of Greece. E/C.12/GRC/CO/2. 
2016. Concluding Observations on the Sixth Periodic Report of the United Kingdom of Great Britain and Northern Ireland. E/C.12/GBR/CO/6.

. 2018. Concluding Observations on the Combined Fifth and Sixth Periodic Reports of Mexico. E/C.12/MEX/CO/5-6.

UN Human Rights Committee. 2004. Concluding Observations: Belgium. CCPR/CO/81/BEL.

- 2009a. Concluding Observations: Sweden. CCPR/C/SWE/CO/6.

2009b. Concluding Observations: Switzerland. CCPR/C/CHE/CO/3.

. 2014a. Concluding Observations on the Third Periodic Report of Latvia. CCPR/ $\mathrm{C} / \mathrm{LVA} / \mathrm{CO} / 3$.

. 2014b. Concluding Observations on the Fourth Periodic Report of the United States of America. CCPR/C/USA/CO/4.

. 2014c. Concluding Observations on the Fourth Periodic Report of Ireland. CCPR/ C/IRL/CO/4.

- 2014d. Concluding Observations on the Second Periodic Report of Malta. CCPR/ $\mathrm{C} / \mathrm{MLT} / \mathrm{CO} / 2$.

- 2015. Concluding Observations on the Sixth Periodic Report of Spain. CCPR/ $\mathrm{C} / \mathrm{ESP} / \mathrm{CO} / 6$.

- 2016. Concluding Observations on the Seventh Periodic Report of Sweden. CCPR/ $\mathrm{C} / \mathrm{SWE} / \mathrm{CO} / 7$.

UN Human Rights Council. 2015. Report of the Special Rapporteur on the Human Rights of Migrants, François Crépeau. A/HRC/29/36.

UN OHCHR (Office of the High Commissioner for Human Rights). 2012. Human Rights Indicators: A Guide to Measurement and Implementation. HR/PUB/12/5.

Van Oers, R., E. Ersbøll, and D. Kostakopoulou (eds). 2010. A Re-Definition of Belonging? Language and Integration Tests in Europe. Leiden: Brill.

Ward, I. 2002. Identifying the European Other. International Journal of Refugee Law 14(2/3): 219-37.

Wiesbrock, A. 2009. Discrimination Instead of Integration? Integration Requirements for Immigrants in Denmark and Germany. In E. Guild, S. Carrera, and K. Groenendijk (eds), Illiberal Liberal States: Immigration, Citizenship and Integration in the EU, pp. 53-106. Ashgate.

Xanthaki, A. 2010. Multiculturalism and International Law: Discussing Universal Standards. Human Rights Quarterly 32(1): 21-48.

- 2016. Against Integration, For Human Rights. International Journal of Human Rights 20(6): 815-38. 